\title{
Analysis of Educational Game Development Needs for Improvement Students' Critical Thinking Ability in Informatics Subjects
}

\author{
Samin*, Gunarhadi, Agus Efendi \\ Master of Educational Technology, Faculty of Teacher Training and Education, Sebelas Maret University
}

*Corresponding author:

E-mail:

saminspd@gmail.com

\begin{abstract}
Critical thinking skills are needed in the learning process, especially in learning Informatics. The use of technology in learning can be done by using learning media in the form of educational games that are integrated in learning. The purposes of this study are 1) to determine the perception of educational games, 2) to obtain information on the need for formats, criteria, content of educational games, 3 ) the role of developing educational games for improving critical thinking skills. The method used in this research is a survey to find out the initial data which is the process of developing educational game products. The instrument used is a questionnaire sheet. The data analysis technique that will be used is quantitative and qualitative descriptive statistical analysis techniques. The schools that were used as research samples were 22 SMP/MTs spread across Karanganyar Regency, Boyolali Regency, and Surakarta City. Each school selected 1 teacher of Informatics Subject and 3 students. The results showed that teachers and students had good perceptions of Informatics educational games. According to the teacher, the need for educational games is games containing evaluation and simulation questions, while adventure-type games are needed by students. The educational game content required includes learning materials, evaluation questions, adventure games, quiz games, simulations. Educational game format needed that is challenging and interesting. Informatics educational game criteria include attractive and interactive design, sufficient duration, usability, easy access, user friendly interface, appropriateness, relevance. Teachers and students believe that educational games can play a role in improving students' critical thinking skills.
\end{abstract}

Keywords: Needs analysis, educational games, critical thinking skills

\section{Introduction}

Learning paradigm of the 21st century is emphasizing the ability of learners to become creative, critical thinking, able to connect with real-world knowledge, master information technology, communicate, and collaborate. Critical thinking is a part of 21st century learning skills. Critical thinking skills are a very important aspect in education that must be developed in facing the challenges of the 21st century. Critical thinking is a directed and clear-thinking process that is used in problem solving, decision making, analyzing and conducting scientific research activities. According to Ennis (2011), critical thinking skills are rational (reasonable) and reflexive thinking skills that focus on beliefs and decisions to be made.

The ability to think critically is an important thing, but the reality on the ground is not as expected. The critical thinking ability of junior high school students in Indonesia is still relatively low. This is based on the four-year International Trends in International Mathematics and Science Study (TIMSS) study conducted on junior high school students with the characteristics of questions at a high cognitive level that can measure students' critical thinking skills, showing that Indonesian students consistently fall in the lower ranks. This also takes place in Informatics learning, 
students have a tendency to not want to think critically even though in informatics subjects generally require critical thinking activities, especially in the basic competencies of Computational Thinking.

Computational thinking (Computational thinking) is one of the Basic Competencies of Informatics Subjects. Computational Thinking is an ability to think to solve a problem comprehensively, logically, and regularly. Computational thinking is a problem-solving technique that has a very wide area of application, not only to solve various problems in everyday life.

Critical thinking skills are very important to have, because critical thinking can be used to solve problems and as a consideration in making correct decisions. Critical thinking is a process, aimed at making reasonable decisions about what to believe and what to do. According to Supandi \& Gymnastics (2019) in the learning process, students' thinking skills can be developed by enriching meaningful experiences through problem solving in class.

According to Prensky (2012) educational games are games designed specifically for learning activities, but can be used to play and have fun. Meanwhile, according to Novaliendry (2013) educational games are games that have been specifically designed to teach students about a particular lesson in developing concepts and understanding, guiding students in practicing abilities, and motivating students to play it. students to learning material in which there is a game so that with a feeling of pleasure it is hoped that students can more easily understand the subject matter that has been delivered by the teacher in learning activities.

The game as an educational medium has several advantages, namely (1) the game is something fun to do and something entertaining; (2) Games allow active participation of students to learn and can provide direct feedback; (3) The game allows the application of concepts or roles into actual situations and roles in society. Skills learned through play are much easier to apply in real life; (4) Games can be used for various educational purposes by changing the tools, rules and problems a little; (5) Games can be easily created and reproduced.

However, efforts to create educational games have not yet reached schools. There are several reasons for this. At first, not all educators and parents believed that educational games could be useful for students. Second, there are criticisms about the quality of existing educational games. For example, Brody in Virvou (2005), shows that the marriage between education and entertainment such as games has resulted in some games that are not very educational and some learning activities that are not very entertaining. Likewise, the application of mobile learning applications based on RPG maker MV can improve students' critical thinking skills, student responses to the use of mobile learning applications based on RPG maker MV in ecosystem learning has very good criteria.

The study revealed that the Yut Nori educational game as a learning medium to train critical thinking skills on the digestive system material developed was declared very feasible in terms of validity with a percentage of $99.3 \%$, the practicality aspect with the percentage of the results of observing the implementation of student activities by $88.4 \%$ and the positive response of students by $98 \%$, and the effectiveness aspect with the percentage of completeness of student learning outcomes by $90 \%$, gain score of 0.44 , and completeness learning indicators by $90 \%$.

This critical thinking ability is very much needed in the learning process, especially in learning Informatics. The students with the lowest level of critical ability are limited to memorizing skills without being able to understand concepts well. The teacher is used to giving examples of questions before the test so that students have difficulty if they are given questions in different forms.

Another factor that causes students' critical thinking ability is still low is that students are not trained and are not accustomed to answering questions with questions that present phenomena. This is in accordance with the opinion to develop students' critical thinking skills, it can be done by always asking and questioning the phenomena being studied.

Furthermore, analyzing the need for educational games is something that must be done to collect information on the needs of educational games from teachers and students that can be used 
to improve the critical abilities of students who are still categorized as low to moderate. Furthermore, the results of this needs analysis can be used to develop an initial design or prototype of an educational game that will be developed.

The above description becomes an important part as well as the reason for. the author to analyze the need for the development of educational games to improve students' critical thinking skills in informatics subjects a.

\section{Material and Methods}

This study uses survey research with the aim of knowing the need for Informatics educational games for junior high school students in SMP/MTs spread across Karanganyar Regency, Boyolali Regency, and Surakarta City. This research was conducted with the respondents of SMP/MTs students and teachers spread across Karanganyar Regency, Boyolali Regency, and Surakarta City. in June to July 2021. The schools that were sampled were 22 SMP/MTs consisting of 15 SMP/MTs in Karanganyar Regency, 5 SMP/MTs in Boyolali Regency, and 2 SMP/MTs in Surakarta City. Each school selected 1 teacher, namely 1 teacher of Informatics Subject and 3 students.

The data collection technique in this study was using an online questionnaire. The data collected include: 1) perceptions of educational games, 2) the need for formats, criteria, content of educational game presentations, 3) the role of developing educational games for improving critical thinking skills.

The data collection instrument used was a questionnaire sheet (questionnaire). The questionnaire compiled includes a closed questionnaire and an open questionnaire. Closed questionnaire using a modified Likert scale with four ratings, Strongly Agree (SS), Agree (S), Doubtful, Disagree (TS) and Strongly Disagree (STS). The instrument used was validated through expert judgment. The data analysis technique that will be used is quantitative and qualitative descriptive statistical analysis techniques. Quantitative descriptive technique by calculating the percentage of the number of answer scores based on the scoring of each answer from the respondents. As for each item statement can be seen in Table 1 .

Table 1. Aspects and items in the questionnaire

\begin{tabular}{|c|c|}
\hline Aspect & Statement/Question Item \\
\hline $\begin{array}{l}\text { 1. Perception of educational game media } \\
\text { a) Teacher and student perception }\end{array}$ & $\begin{array}{l}\text { 1. Know, understand educational games } \\
\text { 2. Learning use educational game become } \\
\text { more interesting and fun } \\
\text { 3. Educational games make learning } \\
\text { fun/entertaining } \\
\text { 4. Educational games can increase stu- } \\
\text { dents' motivation and interest in learn- } \\
\text { ing } \\
\text { 5. Educational games have a positive im- } \\
\text { pact on learning } \\
\text { 6. Developing educational games to inte- } \\
\text { grated in the learning } \\
\text { 7. Educational games can improve stu- } \\
\text { dents' cognitive } \\
\text { 8. Educational games can improve stu- } \\
\text { dents' affective } \\
\text { 9. Educational game can improve stu- } \\
\text { dents' affective } \\
\text { 10. Educational game can improve stu- } \\
\text { dents' critical thinking skills }\end{array}$ \\
\hline
\end{tabular}

To be continued 
11.Educational games can streamline learning time score competition (ranking system) is required in educational games

b) Perception of educational games de-

1. Teachers have not developed learning media in the form of educational games.

2. Teachers are interested in creatinf and developing educational games.

3. Teachers do not yet have the skills/ competence to creat digital based educational games

4. Teachers have obstacles in developing learning media in the form of educational games

c) Use of educational games

1. Supporting the use of educational games as learning media at school \& home

2. Availability of supporting devices for the use of educational games at home (HP, Internet Network)

3. Availability of supporting devices for the use of educational games at home (Computer, Laptop, Internet network)

4. Student/teacher activities access educational games via cellphone

2. Educational game needs

a) Educational game content

1. Educational game contains learning material

2. Educational game contains evaluation questions and feedback

3. Educational game loading adventure game

4. Educational game load quiz game

b) Educational game format

5. Educational game loading simulation

1. Display aspect

2. Content aspect (Content)

3. Aspect of game affordability

4. Challenging \& interesting

c) Criteria for educational games

1. Overall values include good attractive and interactive design, sufficient duration

2. Interface

3. Accuracy

4. Appropriateness

5. Relevant

6. Onjectivity

7. Feedback

3. The role of developing educational games for improving critical thingking skills

1. Educational games are needed in informatics subjects

To be continued 
2. Selection of educational games according to the characteristics and needs of students

3. Educational games play a role in improving students computational thingking skills

4. Educational games play a role in improving students' critical thingking skills

Table 2. Questionnaire scoring guidelines

\begin{tabular}{cc}
\hline Response & Score \\
\hline Strongly agree & 5 \\
Agree & 4 \\
Doubtful & 3 \\
Do not agree & 2 \\
Strongly Disagree & 1 \\
\hline
\end{tabular}

\section{Results and Discussion}

Based on the results of the research that has been carried out, the data collected are 1) perceptions of educational games, 2) the need for formats, criteria, content of educational games, 3) the role of developing educational games for improving critical thinking skills.

\section{Data on teacher and student perceptions of educational games}

The results of the analysis of teachers' perceptions of the development of educational games are presented in Table 3.

Table 3. The Average Score of the Questionnaire Perception of educational game media

\begin{tabular}{ccccc}
\hline \multicolumn{1}{c}{ Aspect } & Statement/Question Item & Range & $\begin{array}{c}\text { Aver- } \\
\text { age }\end{array}$ & $\begin{array}{c}\text { Percent- } \\
\text { age }\end{array}$ \\
\hline 1. Perception of ed-
\end{tabular}

1. Perception of ed-

dia

$\begin{array}{lrlrlr}\begin{array}{l}\text { a) Teacher and Stu- } \\ \text { dent Perception }\end{array} & \begin{array}{l}\text { Know, understand educational } \\ \text { games } \\ \text { learning using educational games } \\ \text { becomes more interesting and } \\ \text { fun }\end{array} & 1-5 & 4.9 & 98 \\ 3 \quad \begin{array}{l}\text { Educational games make learn- } \\ \text { ing fun/entertaining }\end{array} & 1-5 & 4.6 & 92 \\ 4 & \begin{array}{l}\text { educational games can increase } \\ \text { students' motivation and interest } \\ \text { in learning }\end{array} \\ 5 \quad \begin{array}{l}\text { Educational games have a posi- } \\ \text { tive impact on learning }\end{array} & 1-5 & 4.8 & 96\end{array}$

To be continued 


\begin{tabular}{|c|c|c|c|c|c|}
\hline & 6 & $\begin{array}{l}\text { P Developing Educational games } \\
\text { to be integrated in the learning }\end{array}$ & $1-5$ & 4.6 & 92 \\
\hline & 7. & $\begin{array}{l}\text { educational games can improve } \\
\text { students' cognitive }\end{array}$ & $1-5$ & 4.4 & 88 \\
\hline & 8. & $\begin{array}{l}\text { educational games can improve } \\
\text { students' affective }\end{array}$ & $1-5$ & 4.5 & 90 \\
\hline & 9. & $\begin{array}{l}\text { educational games can improve } \\
\text { students' psychomotor }\end{array}$ & $1-5$ & 4.5 & 90 \\
\hline & 10 & $\begin{array}{l}\text { educational games can improve } \\
\text { students' critical thinking skills }\end{array}$ & $1-5$ & 4.75 & 95 \\
\hline & 11 & $\begin{array}{l}\text { educational games can stream- } \\
\text { line learning time }\end{array}$ & $1-5$ & 4.1 & 82 \\
\hline & 12 & $\begin{array}{l}\text { score competition (ranking sys- } \\
\text { tem) is required in educational } \\
\text { games }\end{array}$ & $1-5$ & 4 & 80 \\
\hline & & Average & & 4,5375 & 90.75 \\
\hline $\begin{array}{l}\text { b) Perception of Ed- } \\
\text { ucational Game De- }\end{array}$ & 1. & $\begin{array}{l}\text { Teachers have not developed } \\
\text { learning media in the form of ed- } \\
\text { ucational games }\end{array}$ & $1-5$ & 4.3 & 86 \\
\hline & 2 & $\begin{array}{l}\text { Teachers are interested in creat- } \\
\text { ing and developing educational } \\
\text { games }\end{array}$ & $1-5$ & 5 & 100 \\
\hline & 3 & $\begin{array}{l}\text { Teachers do not yet have the } \\
\text { skills/competence to create digi- } \\
\text { tal-based educational games. }\end{array}$ & $1-5$ & 4.1 & 82 \\
\hline & 4 & $\begin{array}{l}\text { Teachers have obstacles in devel- } \\
\text { oping learning media in the form } \\
\text { of educational games }\end{array}$ & $1-5$ & 4.2 & 84 \\
\hline & & Average & & 4.4 & 88 \\
\hline $\begin{array}{l}\text { c) Use of Educa- } \\
\text { tional Games }\end{array}$ & 1. & $\begin{array}{l}\text { Supports the use of educational } \\
\text { games as learning media at } \\
\text { school \& home }\end{array}$ & $1-5$ & 4.8 & 96 \\
\hline & 2 & $\begin{array}{l}\text { Availability of supporting devices } \\
\text { for the use of educational games } \\
\text { at home (HP, Internet Network) }\end{array}$ & 1 - & 45 & 90 \\
\hline & 3 & $\begin{array}{l}\text { Availability of supporting devices } \\
\text { for the use of educational games } \\
\text { at home (Computer, Laptop, In- } \\
\text { ternet network) }\end{array}$ & & & \\
\hline & 4 & $\begin{array}{l}\text { Student/teacher activities access } \\
\text { educational games via cellphone }\end{array}$ & $1-5$ & 4 & 80 \\
\hline & & Average & & 4,475 & 89.5 \\
\hline & & Total Average & & 4,471 & 89.42 \\
\hline
\end{tabular}


Based on Table 3, it can be seen that the teacher's perception of educational games is in the good category, namely $90.75 \%$ with the highest average value on the indicator that teachers already know and understand educational games with an average value of $98 \%$. One of the points in the aspect of understanding is that learning using educational games becomes more interesting and fun. Teachers and students have the view that educational games can increase students' motivation and interest in learning so that it has an impact on increasing student achievement.

Game is an application that is most widely used and enjoyed by electronic media users today. According to Virvou (2005), game technology can motivate students in learning and involve players so that the learning process is more fun. Basically, game technology can involve players (students) directly so as to motivate students to take part in learning, educational games also have a positive impact on learning

Currently there are many developers who provide educational games, this can be an alternative if the teacher has difficulty in making. Most teachers quite understand that educational games that are currently developing are still dominant in the cognitive domain, and teachers use educational games to improve learning outcomes in the cognitive domain. This explanation can be strengthened with use of games, students can show more cognitive achievement than conventional learning.

Data/information about perception needs to be collected to find out how far the knowledge about educational games is. In addition, perception is an important predictor in the use of further learning resources (Dopo \& Ismaniati, 2016). This is because a good perception by the teacher is a good starting point for teachers and media developers to develop game-based media. Good reception because students and teachers have heard the term educational game from various sources. Various information related to the need for educational games was collected through closed questionnaires, including: availability of supporting facilities and infrastructure, access to educational game media, use of educational game media, material coverage, appearance and ease of navigation.

This is in line with the opinion (Prensky, 2012) educational games are games designed specifically for learning activities, but can be used to play and have fun. Meanwhile, according to (Novaliendry, 2013) educational games are games that have been specifically designed to teach students about a particular lesson in developing concepts and understanding, guiding students in practicing abilities, and motivating students to play it. students to learning material in which there is a game so that with a feeling of pleasure it is hoped that students can more easily understand the subject matter that has been conveyed by the teacher in learning activities.

The development of educational game learning media based on Table 3 of the results of the questionnaire, teachers and students have used games that contain learning materials and are interested in using them. Teachers and students also have a good perception of educational games. The problem that arises is the availability of educational games, teachers do not have the skills to create digital-based educational games so they have not developed educational games. Therefore, the availability of this educational game is a necessity for teachers and students.

One of the points in the aspect of understanding relates to the need for the development of educational games. Teachers have the view that educational games need to be developed to support learning. According to teachers, the provision of educational games in digital form or learning media needs to be held in schools, but teachers also understand that preparing media in the form of games takes a long time. This statement is in line with educational games, which are digital games designed for educational enrichment (supporting teaching and learning), using interactive multimedia technology.

The use of educational games media educational games based on the data in table 3 , the results of the analysis of the needs of students on the use of educational games that teachers and students support the use of educational games as learning media at school \& home. where in the aspect of the availability of supporting facilities and infrastructure more than $90 \%$ of students stated the 
availability of supporting devices for the use of educational games at home (HP, Internet Network).

While in schools the availability of supporting devices for the use of educational games at home (Computers, Laptops, Internet networks) is $90 \%$, Schools already have computers, laptops, Internet networks that can be used when learning with educational games. This is in accordance with the results of the questionnaire that almost all schools already have supporting equipment.

In addition, information is obtained that more than $80 \%$ of students have accessed games via cellphones or smartphones. This is in contrast to the fact that only some teachers are not accustomed to accessing games via cellphones. Some students claimed to have accessed games containing subject matter, and used them as a medium for independent learning (80\%). This is in accordance with the usefulness of educational games that can be used by students in formal and informal learning. Based on the results of the study, it is known that the school already has facilities that support the learning of educational games (computer facilities and Wifi).

Based on the results of the teacher's questionnaire, although they do not often access games every day, they have accessed games that contain learning materials. In addition, most teachers stated that the scope of material in educational games should be adjusted to the core competencies of the subjects. Teachers also agree that games can stimulate critical thinking and problem-solving skills, so that in the development of educational games it is necessary to consider these aspects. This is in accordance with the statement of Corredor et al. (2014) that games are able to stimulate the formation of cognitive structures from different phenomena compared to traditional learning. Yazdi and Zandkarimi (2013) found that there is a significant relationship between cognitive and technology use. According to Felicia (2009) this is because games allow players to learn in a challenging environment where they can make mistakes and learn by doing.

\section{The need for educational games based on the format, criteria, content of the game presenta- tion}

Table 4. Results of the mean questionnaire score data for educational game needs based on the format, criteria, and content of the game presentation

\begin{tabular}{|c|c|c|c|c|c|}
\hline \multicolumn{2}{|l|}{ Aspect } & Statement/Question Item & Range & $\begin{array}{l}\text { Aver- } \\
\text { age }\end{array}$ & $\begin{array}{l}\text { Percent- } \\
\text { age }\end{array}$ \\
\hline \multicolumn{6}{|c|}{ 2. Educational game needs } \\
\hline \multirow[t]{5}{*}{$\begin{array}{l}\text { a) Educational game } \\
\text { content }\end{array}$} & 1. & $\begin{array}{l}\text { Educational game contains } \\
\text { Learning Material }\end{array}$ & $1-5$ & 4.7 & 94 \\
\hline & 2 & $\begin{array}{l}\text { Educational game contains Eval- } \\
\text { uation Questions and Feedback }\end{array}$ & $1-5$ & 4.6 & 92 \\
\hline & 3 & $\begin{array}{l}\text { Educational game loading Ad- } \\
\text { venture game }\end{array}$ & $1-5$ & 4.8 & 96 \\
\hline & 4 & $\begin{array}{l}\text { Educational game load Quiz } \\
\text { Game }\end{array}$ & $1-5$ & 4.7 & 94 \\
\hline & 5 & $\begin{array}{l}\text { Educational game loading Simu- } \\
\text { lation }\end{array}$ & $1-5$ & 4.1 & 82 \\
\hline \multicolumn{4}{|c|}{ Average } & 4.58 & 91.6 \\
\hline \multirow{5}{*}{$\begin{array}{l}\text { b) Educational game } \\
\text { format }\end{array}$} & 1. & Display aspect & $1-5$ & 4.8 & 96 \\
\hline & 2 & Content Aspect (Content) & $1-5$ & 4.9 & 98 \\
\hline & 3 & Aspect of Game Affordability & $1-5$ & 4.2 & 84 \\
\hline & 4 & Challenging \& Interesting & $1-5$ & 5 & 100 \\
\hline & \multicolumn{3}{|c|}{ Average } & 4.73 & 94.50 \\
\hline
\end{tabular}




\begin{tabular}{|c|c|c|c|c|c|}
\hline \multirow[t]{7}{*}{$\begin{array}{l}\text { c) Criteria for educa- } \\
\text { tional games }\end{array}$} & 1. & $\begin{array}{l}\text { Overall Values include good at- } \\
\text { tractive and interactive design, } \\
\text { sufficient duration }\end{array}$ & $1-5$ & 4.8 & 96 \\
\hline & 2 & $\begin{array}{l}\text { Usability, including easy to use, } \\
\text { easy to access, user friendly in- } \\
\text { terface }\end{array}$ & $1-5$ & 5 & 100 \\
\hline & 3 & Accuracy & $1-5$ & 4.6 & 92 \\
\hline & 4 & Appropriateness & $1-5$ & 4.7 & 94 \\
\hline & 5 & Relevant & $1-5$ & 4.8 & 96 \\
\hline & 6 & Objectivity & $1-5$ & 4.2 & 84 \\
\hline & 7 & Feedback & $1-5$ & 4.3 & 86 \\
\hline & \multicolumn{3}{|c|}{ Average } & 4.63 & 92.57 \\
\hline & \multicolumn{3}{|c|}{ Total Average } & 4.64 & 92.89 \\
\hline
\end{tabular}

Referring to the data collected from the questionnaire according to table 4, the format of the educational game developed includes: subject matter, evaluation and feedback questions, adventure games, quiz games, simulations. According to the students' opinion, it is a fun game such as an adventure type game, crossword puzzle and guessing pictures, while according to the teacher, the games developed in learning are games with the type of quizzes, simulations or there are questions (evaluation). The teacher agrees that the animation used must be related to the indicators of the Informatics concept being studied. The appearance of the game must be attractive with animation. In addition, the reward used in the game can be in the form of scores and the challenge is time. These elements must exist as revealed that the characteristics of digital games include (goals, rules, interactive, feedback and challenges).

Educational Games contain educational materials designed in interactive games that aim to increase intelligence. The elements where the concept of educational games is based on the concept of basic education that combines elements, namely: creativity, fun, adventure, motivation, play, skills, freedom, education, logic, hobbies, independence, and decisions. This concept is then adjusted to the user's age classification and learning curriculum. Educational games are digital games designed for educational enrichment.

Educational Game Format refers to research data according to table 4, Educational Game Format contains content (content) aspects, display aspects, game affordability aspects, educational games must challenge and attract users. The main thing that is of concern is to package educational games to be challenging and attractive to users, which is the main focus, after that aspects of content, appearance and affordability of the game. Educational Game is one of the game media that contains the scope of learning materials used to educate students to direct in a fun learning process. Learning using the concept of learning while playing makes students more active in the learning process (Suryawirawati et al., 2018).

As for the overall response, they think that through game media, which is facilitated through technology, it certainly makes the material displayed more attractive and accompanied by clear illustrations so that it is easier to imagine and understand the material. It has been researched previously, related to the integration of entertainment content in games, it can create a pleasant learning climate without compromising the material that students must learn.

Criteria for educational games based on research data in table 4, teachers and students have the criteria for educational games that are needed including: can be used, attractive designs are relevant, appropriate, accurate, objective and provide feedback. This is in line with the opinion of Hurd and Jenuings (2009), a good educational game design must meet the criteria of the education game itself. The following are some of the criteria for an education game, namely: 1). Overall Value: The overall value of a game is centered on the design and length of the game. This application is 
built with an attractive and interactive design. To determine the length of the duration, this application uses the timer feature. 2). Usability: Easy to use and access is an important point for game makers. This application designs a system with a user-friendly interface so that users can easily access the application. 3). Accuracy: Accuracy is defined as how the success of the model/image of a game can be poured into the experiment or design. The design of this application must be in accordance with the game model at the planning stage. 4). Appropriateness: Conformity can be defined as how the content and design of the game can be adapted to the user's needs properly. This application provides menus and features needed by the user to help the user understand how to use the application. 5). Relevant (Relevance): Relevant means that you can apply game content to the target user. In order to be relevant to users, the system must guide them in achieving learning objectives. Because this application is intended for children, the interface design must be in accordance with the nuances of children, namely displaying cheerful colors. 6). Objectivity (Objectives): Objectivity determines the user's goals and criteria for success or failure. In this application objectivity is an attempt to study the outcome of the game. 7). Feedback: To help users understand that their performance matches the game object or not, feedback should be provided. The app provides animations and sound effects that indicate the success or failure of the game.

\section{The role of educational games in improving students' critical thinking skills}

Table 5. The average score of the questionnaire the role of educational games in improving students' critical thinking skills in informatics subjects

\begin{tabular}{llccc}
\hline \multicolumn{1}{c}{ Aspect } & \multicolumn{1}{c}{ Statement/Question Item } & Range & $\begin{array}{c}\text { Aver- } \\
\text { age }\end{array}$ & $\begin{array}{c}\text { Percent- } \\
\text { age }\end{array}$ \\
\hline $\begin{array}{l}\text { 1. The role of educa- } \\
\text { tional games in im- } \\
\text { proving students' crit- } \\
\text { ical thinking skills }\end{array}$ & $\begin{array}{l}\text { Educational games are needed in } \\
\text { Informatics Subjects, especially } \\
\text { Competencies related to theory }\end{array}$ & & & \\
\end{tabular}

2 Selection of educational games

$1-5 \quad 4.75 \quad 95$
according to the characteristics and needs of students

3 Educational Games play a role in improving students' Computational Thinking skills

4 Educational games play a role in improving students' critical thinking skills

Referring to the research results in table 5, teachers and students believe that educational games can play a role in increasing students' critical thinking skills. This educational game is an educational game needed in Informatics Subjects, Selection of educational games according to the characteristics and needs of students, Educational Games play a role in increasing Computational Thinking abilities and also increasing students' critical thinking skills. This is in line with the results of the study that teachers and students realized the significance of the role of educational games in increasing students' critical thinking skills. According to Aini et al. (2018) Critical thinking skills can be trained with learning that requires students to carry out experimental activities, discover and solve problems as well as through small group discussions. Critical thinking skills can be trained through problem analysis, making decisions, trying to understand something, and finding answers to find. Through educational games or learning using computer-assisted learning, 
both individually and in groups, they show better learning activities than students who are not treated with computer-assisted learning or classes with conventional learning systems. The same thing was also expressed by Weay and Masood (2015) that the use of multimedia can improve students' reasoning and critical thinking skills.

According to Supandi and Gymnastics (2019) that the product is in the form of Class VII SMP students, that the educational game learning media "tumpe ritual" developed in the implementation of learning media in the classroom can increase students' active participation so that it has an impact on increasing thinking skills. student critical.

\section{Conclusion}

Based on the research that has been done, it can be concluded: 1) Teachers and students have a good perception of educational games, 2) The need for educational games based on the format, criteria, content of the game presentation. A good educational game contains: subject matter, Evaluation and Feedback Questions, Adventure games, Quiz Games, Simulations. The educational game format includes: material, display and ease of navigation. Criteria for a good game: the design is attractive, relevant, appropriate, accurate, objective and provides feedback. 3) Teachers and students believe that educational games can play a role in improving students' critical thinking skills.

\section{Acknowledgment}

The implication of this research is as an initial needs analysis material for the development of educational games to improve students' critical thinking skills in informatics subjects. This needs to be done as a guide in the development of these educational games or in the development of educational game prototypes in learning. The limitation is that this research is still limited in scope in Karanganyar Regency, Boyolali Regency and Surakarta City. Other regions may have different characteristics or needs for this educational game. This positive response from academics also provides an opportunity for researchers to examine other impacts on the use of this educational game.

\section{References}

Aini, Z, Ramdani, A, \& Raksun, A. (2018). Differences in mastery of biological concepts and critical thinking skills for class X students in the application of the group investigation and guided inquiry cooperative learning model at MAN 1 Praya. MIPA Incandescent Journal, 13(1), 19-23.

Corredor, J., Gaydos, M., \& Squire, K. (20 14). Seeing change in time: video games to teach about temporal change in scientific phenomena. J Sci Educ Technol, 23, 324-343. https://doi.org/doi: 10.1007/s 1 0956-0 1 3-9466-4.

Dopo, F. B., \& Ismaniati, C. (2016). Teachers' perceptions of digital natives, digital learning resources and motivation to use digital learning resources. Journal of Educational Technology Innovation, 3 (1), 1 3-24. https://doi.org/http://dx.doi.org/ 10.21831 /tp.v3i 11.8280

Ennis, R. H (2011). The nature of critical thinking: an outline of critical thinking dispositions and abilities. Chicago: University of Illinois. Felicia, P. (2009). Digital games in school, a handbook for teachers. Belgium: European Schoolnet.

Hurd, D., \& Jenuings, E. (2009). Standardized educational games ratings. Suggested Criteria

Prensky, M. (2012). From digital natives to digital wisdom. New York: P urwoko, Risen.

Supandi, M., \& Gymnastics. (2019). Developing critical thinking skills with the tumpe ritual game. Journal of Science Education Innovation, 5(2), 139-146.

Novaliendry, D. (2013). Interactive multimedia-based geography game application (Case study of class IX Students of SMPN 1 RAO). Journal of Information Technology \& Education, 1(5), 1-9.

Suryawirawati, I. G., Ramdhan, B., \& Juhanda, A. (2018). Analysis of the decrease in students' misconceptions about the concept of global warming with a diagnostic test (two-tier-test) after predict-observe-explain (POE) learning. Journal of Biology Education (JOBE), 1(1), 94-105.

Virvou, M. (2005). Combining software games with education: evaluation of its educational effectiveness. Journal of Educational Technology and Society, 8(2), 54-65. 
Weay, A. L., \& Masood, M. (2015). The 'big picture' of thematic. Multimedia Information.

Yazdi \& Zandkarimi. (2013). The impact of e-learning on some psychological dimensions and academic achievement. International Journal of Education and Learning, 2(2), 49-56

Yulianti, D. \& Wiyanto. (2009). Innovative learning design. Semarang: Semarang State University. 